\title{
Analisis Pesan Dakwah pada Kisah Dua Putera Adam dalam Alquran
}

\author{
Muhammad Haramain \\ IAIN Parepare \\ e-mail: haramain84@gmail.com
}

\begin{abstract}
Abstrak
Studi artikel ini memfokuskan pada nilai-nilai dakwah yang dapat diambil dari dua putra kisah Adam di Alquran, yang oleh penafsiran cendekiawan Islam disusun oleh kisah Qabil dan Habil. Studi ini menunjukkan bahwa: (a) integritas rasa takut dan niat seseorang adalah salah satu syarat menerima layanan agama selain Allah. Hal ini diambil dalam sikap yang dimiliki oleh Habil ketika akan mendedikasikan dirinya. Itu sebabnya agar pengorbanan diterima selain Allah. Berbeda dengan Qabil, karena ia tidak jujur dalam melaksanakan pengorbanan, menyebabkan pengorbanan yang ditolak oleh Allah swt.; (B) kepala suci yang dimiliki oleh seseorang akan dapat memiliki perintah atas dia saya saya tentang kejahatan. Hal ini ditarik di kepala Habil yang mampu dikuasai, sehingga dia tidak memberikan perlawanan ketika Qabil melakukan kejahatan pembunuhan terhadap dirinya sendiri; (c) mencabut pelajaran saya dan situasi makhluk ciptaan Tuhan adalah hal lain, termasuk hal-hal penting. Salah satu contohnya adalah saya gagak yang menginspirasi Qabil mengenai prosedur menguburkan mayat.
\end{abstract}

Kata Kunci: Pesan Dakwah, Adam, Qabil, Habil

\begin{abstract}
This article study focueses on da'wah values that can be taken from two sons of Adam story in Alquran, which by Islamic scholar interpretation conceived by story of Qabil and of Habil. This study indicates that: (a) integrity of fear and intention for someone is one of condition accepted the religious service of beside Allah. This Matter is drawn in attitude had by Habil when will dedicate his him. That is why so that the sacrifice of accepted beside Allah. Differing from of Qabil, because he is dishonest in executing sacrifice, causing the sacrifice of the refused by Allah swt.; (b) holy head which owned by someone will be able to have a command over him of my me of badness. This matter is drawn in head of Habil capable to have a command over, so that he not give resistance when Qabil conduct badness of murder to x'self; (c) pluck Iesson of my me and situation of God creation creature is other, including important matter. One of the example is my me of raven which inspiring Qabil concerning procedures entomb dead body.
\end{abstract}

Keywords: Pesan Dakwah, Adam, Qabil, Habil 


\section{PENDAHULUAN}

Alquran sebagai kitab suci umat Islam, menyebutkan fungsinya yang utama sebagai petunjuk (M. Quraish Shihab, 1992: 33), pembawa rahmat (alShabuniy, t.th.: 173), penawar derita (al-Shabuniy, t.th.: 172), peringatan dalam rentang kegembiraan dan ancaman(al-Shabuniy, t.th.: 458), dan pembeda antara yang benar dan yang batil (Al-Shabuniy, t.th.: 184). Semua fungsi tersebut ditujukan untuk manusia dan totalitasnya, khususnya bagi orang-orang yang meyakini kebenarannya (M. Radhi Al-Hafid, 1994: 1).

Selain Alquran membawa petunjuk di bidang akidah, syariat, dan akhlak, juga mengandung kisah. Kisah-kisah yang dimaksud, ditemukan dalam 1508 ayat. Dalam frekuensi yang banyak itu, tersebar pada 45 surah (M. Radhi Al-Hafid, 1998: 4). Kisah-kisah tersebut merupakan salah satu aspek kemukjizatan Alquran yang sangat menarik untuk dikaji dan dikembangkan, sebab di dalamnya termuat berita-berita tentang keadaan umat terdahulu, pengalaman para nabi sebelum Nabi Muhammad, dan beberapa peristiwa yang telah terjadi (Manna' al-Qaththan, t.th.: 306).

Dari sekian banyak kisah masa lampau yang diungkap Alquran, diakui bahwa ada di antaranya yang tidak atau belum dibuktikan kebenarannya hingga kini, tetapi sebagian lainnya telah terbukti melalui penelitian antropologi dan arkeologi (Azyumardi Azra, 1999: 125-126). Meski terdapat sekian banyak kisah Alquran yang belum terbukti, namun tidaklah wajar menolak kisah yang ada hanya dengan alasan itu. Sebab, apa yang belum terbukti kebenarannya, juga belum terbukti kekeliruannya (M. Quraish Shihab, 1998: 195). Di samping itu, yang terpenting adalah makna yang terkandung dalam kisah itu dapat dijadikan pelajaran hidup bagi manusia.

Salah satu di antara kisah Alquran yang menarik untuk dikaji ialah kisah dua putera Adam, yang dalam versi riwayat israiliyat disebut sebagai Qabil dan Habil (al-Khalidiy, 2000: 84). Kisah ini termuat dalam QS al-Maidah (5): 27-31.

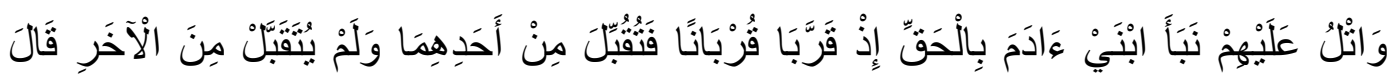

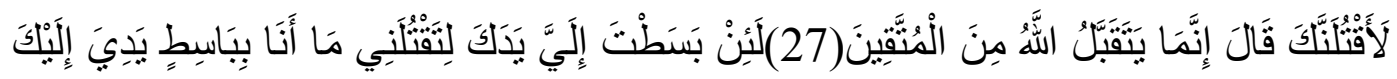




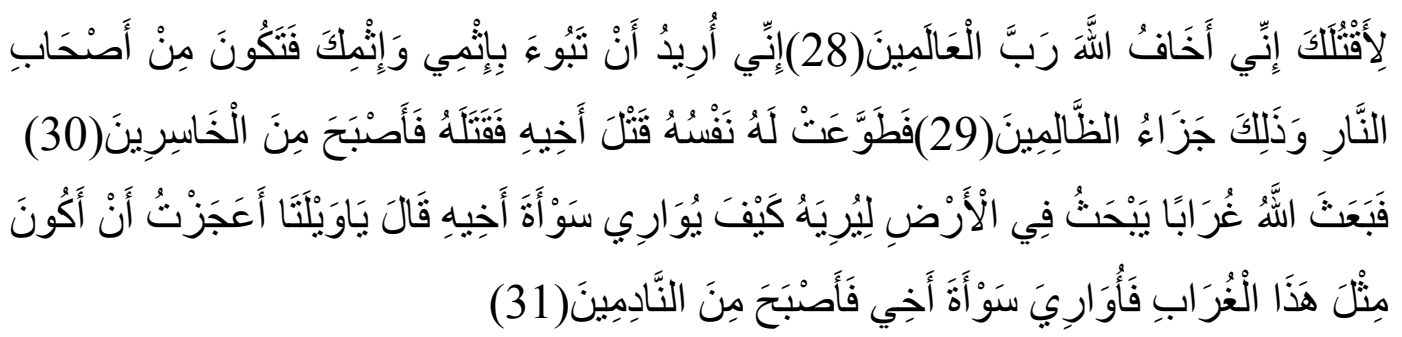

Terjemahnya:

Ceriterakanlah kepada mereka kisah kedua putera Adam (Habil dan Qabil) menurut yang sebenarnya, ketika keduanya mempersembahkan kurban, maka diterima dari salah seorang dari mereka berdua (Habil) dan tidak diterima dari yang lain (Qabil). Ia berkata (Qabil): "Aku pasti membunuhmu!" Berkata Habil: "Sesungguhnya Allah hanya menerima (korban) dari orang-orang yang bertakwa". "Sungguh kalau kamu menggerakkan tanganmu kepadaku untuk membunuhku, aku sekali-kali tidak akan menggerakkan tanganku kepadamu untuk membunuhmu. Sesungguhnya aku takut kepada Allah, Tuhan seru sekalian alam". "Sesungguhnya aku ingin agar kamu kembali dengan (membawa) dosa (membunuh) ku dan dosamu sendiri, maka kamu akan menjadi penghuni neraka, dan yang demikian itulah pembalasan bagi orang-orang yang zalim". Maka hawa nafsu Qabil menjadikannya menganggap mudah membunuh saudaranya, sebab itu dibunuhnyalah, maka jadilah ia seorang di antara orang-orang yang merugi. Kemudian Allah menyuruh seekor burung gagak menggali-gali di bumi untuk memperlihatkan kepadanya (Qabil) bagaimana dia seharusnya menguburkan mayat saudaranya. Berkata Qabil: "Aduhai celaka aku, mengapa aku tidak mampu berbuat seperti burung gagak ini, lalu aku dapat menguburkan mayat saudaraku ini?" Karena itu jadilah dia seorang di antara orang-orang yang menyesal.

Alur kisahnya menyebutkan bahwa kedua putera Adam tersebut diperintahkan berkurban oleh Allah swt. Salah satu di antara mereka diterima persembahan kurbannya, sedangkan yang satunya lagi ditolak. Akibatnya, terjadilah pembunuhan terhadap salah satu di antaranya. Dalam keadaan bingung karena tidak tahu harus dibawa ke mana jenazah saudaranya, maka Allah mengutus dua burung gagak untuk memberi contoh cara menguburkan mayat.

Jika dianalisis secara cermat kisah di atas, akan ditemukan beberapa nilai edukatif di dalamnya, yang apabila mampu ditransfer dalam proses kehidupan manusia, dapat dipastikan akan membawa pengaruh yang positif dalam meningkatkan keimanan dan ketakwaan kepada Allah, sekaligus dapat menimbulkan kedamaian dalam kehidupan bermasyarakat. 


\section{PEMBAHASAN}

\section{Kisah Pengorbanan, Pembunuhan, dan Penguburan oleh Dua Orang Putera} Adam

Kalau ditelaah secara cermat QS al-Maidah (5): 27-31, Alquran tidak menyebut waktu, tempat, dan nama-nama tokoh pemeran kisah. Oleh karena itu, muncul berbagai penafsiran ulama mengenai jalannya peristiwa kisah tersebut. Perbedaan penafsiran tersebut, tidak hanya menyangkut waktu dan tempat terjadinya peristiwa, tetapi juga nama-nama dari tokoh yang terkait dalam kisah juga tidak disepakati.

\section{Waktu, Tempat, dan Tokoh Kisah}

Al-Hasan al-Bashriy berkata bahwa dua anak Adam yang dimaksud dalam ayat tersebut, bukan anak kandung Adam, tetapi dua orang dari Baniy Isra'il. Keduanya berselisih ketika mempersembahkan kurban. Tidak ditemukan adanya perintah berkurban, kecuali dari Baniy Isra'il (al-Qurthubiy, 1967: 133). Alasannya adalah firman Allah yang disebutkan dalam QS al-Maidah (5): 32 yang menyebutkan ketentuan hukum pembunuhan bagi Baniy Isra'il. Sekiranya pembunuhan itu terjadi pada anak kandung Adam, tidak mungkin peristiwa itu menjadi latar belakang diwajibkannya hukum kisas bagi Baniy Isra'il (al-Khalidiy, 2000: 87).

Jumhur Ulama Tafsir, seperti Ibn 'Abbas dan Ibn 'Umar berpendapat bahwa dua putera Adam yang dimaksudkan adalah anak kandung Adam yang hidup bersamanya, yaitu Qabil dan Habil. Kisah ini pun terjadi pada masa Nabi Adam. Dalam kaitan ini, Ibn 'Athiyah berkata bahwa jika keduanya dari Baniy Isra'il, tidak mungkin salah seorang darinya tidak mengetahui cara menguburkan mayat saudaranya, sehingga burung gagak menunjukkan kepadanya (alQurthubiy, 1967: 133). Ini merupakan bukti bahwa peristiwa itu terjadi pada masa-masa awal sejarah kehidupan manusia di bumi. Tampaknya, ini merupakan dosa pembunuhan pertama yang dilakukan dengan sengaja di atas permukaan bumi ini. (al-Khalidiy, 2000: 88) 
Dari perbedaan pendapat tersebut, tampaknya pendapat yang dikemukakan oleh jumhur dinilai lebih kuat, sebab secara sosiologis, cara penguburan mayat sudah dikenal dalam sejarah agama-agama samawi sebelum adanya Baniy Isra'il. Di samping itu, diperkuat pula dengan penggunaan kata ibnay Adam, bukan baniy Adam. Penggunaan kata ibnay Adam dalam ayat ini merupakan bukti kuat bahwa peristiwa itu terjadi pada dua anak kandung Adam. Satu-satunya ayat dalam Alquran yang menggunakan kata ibnay Adam, hanya dalam kisah ini. Berbeda dengan ayat-ayat lainnya yang menyinggung anak cucu Adam secara umum, kesemuanya menggunakan kata baniy Adam.

Selain dari argumen di atas, terdapat pula sebuah Hadis Nabi yang memperkuat pendapat jumhur. Adapun Hadis Nabi yang dimaksud adalah sebagai berikut:

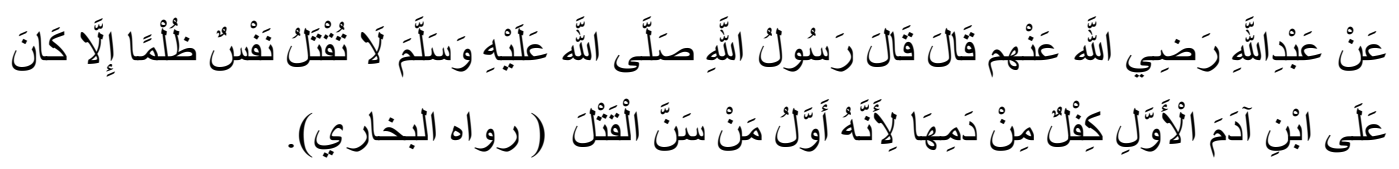

Artinya:

Dari 'Abdillah ra. berkata, Rasulullah saw. bersabda: "Tidaklah dibunuh jiwa secara lalim, kecuali atas anak Adam yang pertama, karena dia adalah orang yang pertama melakukan pembunuhan" (HR al-Bukhariy).

Adapun yang dimaksud dengan jiwa yang dibunuh secara lalim dalam Hadis Nabi di atas adalah Habil, sedangkan orang yang pertama melakukan pembunuhan adalah Qabil. Dengan demikian, Hadis Nabi tersebut memperkuat argumen jumhur yang mengatakan bahwa kisah yang diceritakan dalam QS alMaidah (5): 27-31 adalah kisah nyata yang betul-betul terjadi. Dua anak Adam yang dimaksudkan itu adalah anak kandungnya sendiri yang hidup bersamanya, dan kisah ini pun terjadi pada zaman Nabi Adam (al-Khalidiy, 2000: 88).

Datangnya burung gagak menggaruk-garuk tanah yang mengilhami Qabil untuk menguburkan mayat Habil, semakin memperkuat argumentasi jumhur bahwa Qabil sebagai pembunuh pertama dan hidup di awal sejarah kemanusiaan, sudah dipastikan bahwa ia belum pernah menyaksikan penguburan mayat. Karenanya, contoh yang diterima oleh burung gagak betul-betul merupakan ilmu 
baru baginya, sehingga pada saat itu ia merasa dirinya jauh lebih bodoh daripada burung gagak.

Selain penafsiran yang telah dikemukakan Hasan al-Bashriy dan Jumhur Ulama Tafsir, ada pula ulama yang berpendapat bahwa dua anak Adam yang disebutkan dalam kisah ini hanya berupa simbol semata, tidak pernah terjadi di dunia nyata. Sayyid Quthub (1971: 73-74) misalnya berkata bahwa ayat yang menjelaskan kisah ini tidak menyebut waktu, tempat, dan nama-nama pelakunya. Ia lebih cenderung membiarkan kisah ini apa adanya, tanpa memberikan batasan tertentu. Membiarkan kisah ini secara mujmal, justeru akan mencapai tujuan pemaparan, isyarat-isyarat, dan pengarahan kisah secara sempurna, tanpa menambah rincian-rincian lain kepada tujuan pokoknya. Di satu sisi, pendapat Sayyid Quthub ini memberi petunjuk kepada para pengkaji Alquran agar tidak tergesa-gesa dalam menafsirkan ayat-ayat Alquran. Namun, di sisi lain dapat dikatakan bahwa pendapat tersebut membunuh kreativitas para ilmuan untuk melakukan pengkajian yang lebih komprehensif mengenai kandungan ayat-ayat Alquran.

\section{Kisah Pengorbanan}

\section{Latar Belakang Terjadinya Pengorbanan}

Menurut Wahbah al-Zuhaliy (t.th.: 153), latar belakang pengorbanan yang dilakukan Qabil dan Habil disebabkan oleh perselisihan dalam penentuan jodoh. Aturan perkawinan yang berlaku pada masa itu adalah kawin silang. Qabil tidak boleh kawin dengan saudari kembarnya, demikian pula sebaliknya bagi Habil. Namun, Qabil menginginkan kawin dengan saudari kembarnya, karena parasnya lebih cantik daripada saudari kembar Habil. Adam menolak keinginan Qabil tersebut, karena menyalahi aturan perkawinan yang berlaku. Akibatnya, timbullah ketegangan di antara mereka. Untuk menyelesaikan masalah ini, maka diperintahkanlah kepada keduanya berkorban. Kurban yang dipersembahkan oleh Habil diterima oleh Allah, sedangkan kurban Qabil ditolak oleh Allah.

Dalam uraian yang berbeda, Bey Arifin (t.th.: 29-31) menuturkan bahwa kegiatan berkurban bagi keduanya sudah dilakukan sejak masih remaja. Adam 
telah membagi pekerjaan kepada kedua anaknya. Qabil bekerja sebagai petani, sedangkan Habil bekerja sebagai peternak hewan. Untuk menguji kesyukuran kedua anaknya itu, Adam memerintahkan mereka mengorbankan sebagian dari hasil pekerjaannya. Pada saat itu, kurban Habil diterima karena memilih ternaknya yang baik untuk dikurbankan, sedangkan kurban Qabil ditolak oleh Allah karena memilih hasil pertaniannya yang jelek lagi busuk untuk dikurbankan.

Uraian Bey Arifin (t.th. 32-37) menunjukkan peristiwa berkurban ini merupakan awal timbulnya kebencian Qabil terhadap Habil. Kemarahan dan kebencian tersebut semakin diperparah oleh aturan perkawinan yang ditetapkan kepada mereka setelah beranjak dewasa. Qabil menolak peraturan untuk kawin dengan adik Habil yang dianggapnya tidak cantik. Dengan diperbudak oleh Iblis, Qabil melampiaskan kebenciannya dengan membunuh Habil. Hal ini menunjukkan bahwa Bey Arifin tidak menganggap perselisihan dalam penentuan jodoh sebagai latar belakang terjadinya pengorbanan.

Hal lain yang menarik dalam bagian kisah ini adalah perbedaan pendapat ulama mengenai nama pasangan kembar Qabil dan Habil. Meski pada umumnya ulama tafsir sepakat menyebut kedua anak Adam tersebut sebagai Qabil dan Habil, tetapi mereka tidak sepakat mengenai nama pasangan perempuan mereka.

Al-Qurthubiy (1967: 133) dan al-Syawkaniy (1973: 30) mengatakan bahwa pasangan kembar Qabil bernama Iqlima, sedangkan pasangan kembar Habil bernama Layudha. Bahkan, Ja'far al-Shadiq menyebutkan bahwa Adam tidak mengawinkan anaknya dengan sesama anaknya sendiri, tetapi mengawinkan mereka dengan keturunan Jin yang berbentuk manusia. Qabil dijodohkan dengan putri Jin yang bernama Jamalah, sedangkan Habil dijodohkan dengan Bazlah (alQurthubiy, 1967: 133).

Perbedaan pendapat tersebut merupakan suatu kewajaran, sebab kemungkinan sumber rujukan yang digunakan masing-masing ulama tersebut berbeda, sehingga penulis berasumsi bahwa pendapat-pendapat tersebut tidak perlu ditelusuri kekuatan dan kelemahannya masing-masing. 


\section{Benda yang Dijadikan Kurban}

Sebagaimana halnya dengan latar belakang pengorbanan, benda yang dijadikan sebagai persembahan kurban oleh kedua putera Adam, juga tidak disebut dalam QS al-Maidah (5): 27.

Dalam memberikan interpretasi tentang masalah ini, para mufassir mengutip sebuah riwayat dari Ibn 'Abbas yang mengatakan bahwa salah seorang dari kedua anak Adam itu bekerja sebagai petani, sedangkan yang seorang lagi sebagai pengembala kambing. Ketika mereka diperintahkan berkurban, yang bekerja sebagai petani itu mengambil hasil pertaniannya yang jelek dan busuk disertai dengan hati dongkol. Adapun yang bekerja sebagai peternak kambing, ia mengambil kambingnya yang gemuk dan bagus disertai dengan hati yang suci (alMaragiy, t.th.: 97-98).

Keterangan dari Bey Arifin (t.th.: 29-30) menyebutkan bahwa ketika Adam mengetahui watak antara Qabil dan Habil yang jauh berbeda, maka ia membagi pekerjaan kepada masing-masing anaknya itu sesuai dengan wataknya. Qabil yang diketahui memiliki watak yang keras dan kasar, diserahi pekerjaan sebagai petani, sedangkan Habil yang dinilai wataknya lembut dan halus, diberikan tugas sebagai peternak kambing. Ketika keduanya diperintahkan berkurban, maka Qabil yang bekerja sebagai petani itu mengambil hasil pertaniannya yang jelek dan busuk untuk dikurbankan. Adapun Habil yang bekerja sebagai peternak, memilih binatang ternaknya yang gemuk dan bagus untuk dipersembahkan.

Dari keterangan mufassir di atas, dapat diketahui bahwa dalam melaksanakan ibadah kurban, tidaklah ditentukan jenis benda atau barang yang harus dikurbankan, tetapi tergantung kepada hasil pekerjaan yang ditekuni oleh masing-masing individu yang ingin berkurban tersebut. Hal ini cukup logis, sebab menentukan jenis benda atau barang yang harus dikurbankan, dapat menimbulkan kesulitan bagi individu yang tidak memiliki benda atau barang seperti itu. Sementara itu, Allah tidak pernah membebani seseorang terhadap apa yang ia tidak mampu memikulnya.

\section{Cara Mengetahui Kurbannya Diterima}


Wahbah al-Zuhailiy (t.th.: 154) ketika memberikan keterangan lanjutan mengenai cara keduanya mengetahui diterima atau ditolaknya kurban yang dipersembahkan itu, mengatakan bahwa Adam memanggil Qabil dan Habil naik ke puncak gunung dan menyuruh keduanya meletakkan persembahan kurbannya masing-masing. Setelah menunggu tiga hari lamanya, mereka bertiga sama-sama naik ke atas gunung tersebut untuk melihat hasil pengurbanannya. Pada saat itu, Allah mengirim api untuk melalap kurban yang diterima, maka terbakar hanguslah kurban Habil, sedangkan kurban Qabil tidak dilalap api. Melihat kejadian itu, Qabil berkata: "Hai Habil, kurbanmu diterima, sedangkan kurbanku ditolak. Akan ku bunuh kamu". Habil menjawab: "Saya mempersembahkan hartaku yang terbaik, sedangkan engkau mempersembahkan hartamu yang terburuk. Sesunggunya Allah tidak menerima, kecuali yang terbaik".

Bey Arifin juga menceritakan hal yang serupa, tetapi tidak menyebutkan batas waktu menunggu bagi mereka selama tiga hari. Begitu pula tidak menyebut adanya api yang datang melalap kurban Habil, sebagai bukti pengorbanannya diterima (Bey Arifin, t.th.: 31).

Keterangan di atas menunjukkan bahwa penyebab ditolaknya kurban Qabil, paling tidak disebabkan oleh dua faktor. Pertama, Qabil dalam mempersembahkan kurban itu memilih hartanya yang tidak berkualitas baik. Kedua, dalam mempersembahkan kurban itu, niatnya tidak ikhlas atau hanya dalam keadaan terpaksa. Sebaliknya, Habil diterima kurbannya oleh Allah, juga disebabkan oleh dua faktor. Pertama, Habil memilih hartanya yang terbaik kualitasnya untuk dikurbankan. Kedua, dalam mempersembahkan kurbannya itu, niatnya suci dan ikhlas.

\section{Kisah Pembunuhan}

Karena merasa jengkel kurbannya ditolak oleh Allah, maka Qabil bermaksud membunuh Habil. Ini dipahami dari ungkapan Qabil yang berbunyi: لأقتلنك (aku pasti membunuhmu), sebagaimana tercantum dalam QS al-Maidah (5): 27. Hal ini menunjukkan bahwa hati Qabil telah dikuasai oleh kejahatan dan dengki terhadap saudaranya. Setan mengalahkannya dan menutup hatinya dari 
kebenaran. Sesungguhnya ia mengetahui dirinya tidak berada pada pihak yang benar. Seharusnya ia mengoreksi sikap dan tingkah lakunya yang menyebabkan kurbannya ditolak oleh Allah. Setan telah menggiring Qabil kepada tingkatan yang paling berbahaya, yaitu berpikir dan merencanakan untuk membunuh saudaranya.

Mendengar ancaman Qabil, Habil memberi jawaban bahwa dirinya tidak akan melakukan hal yang serupa, yaitu bermaksud membunuh Qabil. Artinya, dalam peristiwa itu, Habil sama sekali tidak memberikan perlawanan dalam mempertahankan diri. Dari peristiwa ini dapat diketahui watak dan tabiatnya masing-masing, sekaligus merupakan dua contoh tipe manusia yang berbeda di antara dua orang bersaudara.

Dalam kaitan ini, Sayyid Quthub (1971: 703) berkata bahwa kisah ini memberikan contoh tabiat yang buruk dan sifat permusuhan. Di samping itu, juga memberikan contoh dari tabiat yang baik, jiwa pemaaf, dan sifat kelembutan. Kedua orang bersaudara itu masing-masing bersikap sesuai dengan tabiat yang dimilikinya.

Meski mendapat peringatan dari saudaranya agar kembali ke jalan yang benar, namun Qabil dengan rasa dendamnya yang menyala-nyala, menyebabkan ia tetap melakukan kejahatan yang direncanakannya, yaitu membunuh Habil.

Kalau ditelusuri ayat-ayat yang mengisahkan peristiwa ini, tidak ditemukan penjelasan mengenai cara yang ditempuh dan benda apa yang digunakan oleh Qabil untuk membunuh Habil. Penjelasan mengenai hal ini ditemukan pada penjelasan para mufassir.

Wahbah al-Zuhailiy (t.th.: 154) misalnya, menjelaskan bahwa ketika kemarahan Qabil memuncak, maka dia mengambil sepotong besi dan memukulkannya kepada Habil. Pada saat itu, Habil jatuh tersungkur dan meninggal dunia.

Versi israiliyat dalam hal ini mengatakan bahwa pada waktu Qabil datang untuk membunuh saudaranya, Habil menghindar dan melarikan diri ke puncak gunung. Pada suatu hari, Qabil mendatangi Habil yang sedang tidur, lalu ia 
mengangkat batu besar dan memecahkan kepala Habil. Habil meninggal dalam usia 20 tahun di atas puncak gunung Qosiyun, Damaskus (al-Khalidiy, 2000: 85).

Dari keterangan di atas, dapat dipahami bahwa benda yang digunakan Qabil dalam membunuh Habil adalah benda yang keras, ada yang mengatakan sepotong besi, ada yang mengatakan sepotong dahan kayu, dan ada yang mengatakan sebuah batu besar. Benda apa pun yang digunakan Qabil dalam membunuh Habil, tidaklah menjadi masalah, karena yang jelas bahwa Qabil telah melakukan kegiatan pembunuhan terhadap saudaranya secara terencana. Habil pun mengetahui bahwa kakaknya bermaksud membunuhnya, tetapi ia tidak melakukan perlawanan, apalagi memiliki niat yang sama untuk membunuh kakaknya, karena ia mengetahui bahwa perbuatan seperti itu merupakan dosa besar yang akan dipertanggungjawabkan di hadapan Allah di hari kemudian.

\section{Kisah Penguburan}

Dalam QS al-Maidah (5): 31 dijelaskan bahwa Allah mengirim burung gagak menggaruk-garuk di bumi, sebagai contoh bagi pembunuh untuk menguburkan saudaranya. Melihat contoh itu, pembunuh menyadari kebodohan dirinya yang tidak mampu berbuat seperti halnya burung gagak itu.

Untuk merinci keumuman makna ayat di atas, para mufassir berusaha menjelaskan renteten peristiwa yang terjadi setelah terjadinya pembunuhan Qabil terhadap Habil, termasuk perbedaan pendapat mengenai jumlah burung gagak yang datang memberi contoh, apakah seekor atau dua ekor?.

Dalam kaitan ini, Wahbah al-Zuhailiy (t.th: 155) mengatakan bahwa, setelah terjadinya pembunuhan itu, Qabil merasa kebingungan, ia tidak tahu bagaimana cara menguburkan mayat Habil. Dalam suasana kebingungan itu, Allah mengutus dua ekor burung gagak, keduanya berkelahi, kemudian salah satu di antaranya membunuh temannya. Burung gagak yang masih hidup itu menggaruk-garuk tanah, dan setelah itu ia menarik temannya yang terbunuh ke dalam lobang dan menimbunnya dengan tanah. Melihat kejadian itu, Qabil menyadari kebodohan dirinya yang tidak bisa berbuat sebagaimana halnya perbuatan seekor burung. 
Cerita yang senada dengan sedikit tambahan, Bey Arifin (t.th.: 38-39) mengatakan bahwa, setelah melakukan pembunuhan, Qabil tidak tahu apa yang harus dilakukannya. Ia kemudian memikul jenazah saudaranya dan dibawanya berjalan tanpa arah. Ketika sedang cape, ia berhenti melepaskan lelah. Tiba-tiba ia melihat dua ekor burung gagak berkejar-kejaran dan hinggap di tanah. Keduanya berkelahi, saling patuk mematuk dengan paruhnya masing-masing. Salah satu darinya terkena patuk yang keras sehingga lehernya patah, kemudian ia mati. Burung gagak yang masih hidup menggali lobang dengan mempergunakan kaki dan paruhnya. Setelah lobang itu menjadi besar dan dalam, ia menarik temannya yang sudah mati itu ke dalam lobang, lalu ditutupnya lobang itu dengan tanah. Setelah itu, burung gagak tersebut terbang meninggalkan tempat itu. Melihat kejadian itu, Qabil berkata kepada dirinya: "Rupanya aku lebih bodoh daripada burung gagak itu”. Qabil kemudian menggali lobang dan menguburkan mayat saudaranya.

Hamka (1992: 220) mengemukakan pendapat yang berbeda. Ia mengatakan bahwa ketika saudaranya menjadi bangkai, Qabil tidak tahu akan dikemanakan bangkai itu. Dalam keadaan bingung tersebut, datanglah seekor burung gagak mengorek-ngorek tanah, ia mencari makanan di bawah tanah. Setelah menggali, biasanya burung gagak itu menimbunnya kembali. Waktu melihat peristiwa itu, barulah Qabil tahu bagaimana caranya menguburkan bangkai saudaranya.

Menanggapi perbedaan pendapat di atas, al-Khalidiy (2000: 103) mengatakan bahwa berapakah jumlah burung gagak, satu atau dua ekor? Apakah burung gagak itu saling membunuh? Apakah burung gagak yang membunuh membuat lobang di tanah untuk mengubur mayat gagak yang terbunuh? Pertanyaan-pertanyaan ini tidak ada jawabannya, sebab Alquran dan Hadis Nabi tidak memberikan jawaban atas peristiwa tersebut.

Kalau diperhatikan QS al-Maidah (5): 31, disebutkan bahwa yang diutus oleh Allah hanya seekor burung gagak. Artinya, ayat ini cukup jelas menyebutkan hanya seekor burung gagak. Adapun tujuan burung gagak itu menggali di tanah, bisa jadi untuk mencari makanan, atau datang membawa makanan untuk disimpan 
di bawah tanah, atau datang dengan membawa bangkai burung gagak lain dan menguburkannya.

Dalam kaitan ini, M. Quraish Shihab (1997: 74) mengatakan bahwa, apa pun tujuan burung gagak itu menggali, tidaklah menjadi penting. Hal yang jelas bahwa upayanya menggali tanah telah mengilhami Qabil untuk menanam bangkai saudaranya yang terbunuh, karena ia mengetahui cara penguburan setelah melihat burung gagak menggali.

Selanjutnya, Sayyid Quthub (1971: 706-707) mengatakan bahwa tampaknya si pembunuh belum mengerti sebelumnya mayat itu harus dikubur. Ada dua kemungkinan yang bisa muncul dalam masalah ini: Pertama, mungkin mayat adalah mayat pertama di muka bumi dari anak kandung Adam. Kedua, mungkin juga si pembunuh usianya masih sangat muda dan belum pernah ia melihat mayat dikuburkan.

\section{Analisis Pesan dakwah dalam Kisah Dua Putera Adam}

\section{Ketulusan Niat dan Ketakwaan sebagai Syarat Diterimanya Ibadah}

Ibadah (ibadat) adalah sebuah kata yang sudah baku dalam Bahasa Indonesia, yang dalam Kamus Besar Bahasa Indonesia mempunyai dua arti. Pertama, perbuatan untuk menyatakan bakti kepada Allah yang didasari ketaatan mengerjakan perintah-Nya dan menjauhi larangan-Nya. Kedua, segala usaha lahir dan batin sesuai dengan perintah Tuhan untuk mendapatkan kebahagiaan dan keselarasan hidup, baik terhadap diri sendiri, keluarga, masyarakat, maupun terhadap alam semesta (Departemen Pendidikan dan Kebudayaan, 1988: 364). Dalam Kamus al-Munawwir (t.th: 951-952) dikemukakan bentuk tashrif dari kata . Kata 'abdun berarti budak, yang selanjutnya berubah menjadi 'ibadatun yang berarti taat disertai tunduk, kemudian ta'abbud berarti mensucikan diri dengan beribadah, kemudian mu'abbad berarti orang yang dihormati seolah-olah ia disembah.

Dari uraian yang telah dikemukakan di atas, dapat dipahami bahwa ibadah berarti tunduknya seseorang terhadap ketinggian dan keunggulan orang lain, sehingga ia turun dari derajat kebebasan dan melepaskan kemerdekaannya untuk 
orang tersebut, dengan meninggalkan semua perlawanan dan mengikutinya dengan patuh. Seorang hamba, tidak hanya cukup menyerahkan diri kepada tuannya dengan taat dan merendahkan diri, tetapi di samping itu ia harus meyakini ketinggian dan keunggulannya. Setiap individu dapat mengerjakan ibadah yang sesuai dengan kemampuan dan kewenangannya. Hakikat ibadah adalah untuk menumbuhkan kesadaran diri bahwa setiap manusia diciptakan untuk mengabdi gepada Allah. Hal ini tergambar dalam QS al- ${ }^{a}$ ariyat (51): 56 yang berbunyi: خلقت الجن و الإنس إلا ليعبدون Dan Aku tidak menciptakan jin dan manusia melainkan supaya mereka menyembah-Ku).

Dengan beribadah hanya kepada Allah, manusia dapat membebaskan diri dari berbagai bentuk penghambaan terhadap sesama makhluk, sebab inti ajaran Islam hanya menjadikan Allah sebagai satu-satunya Tuhan yang wajib disembah (al-Maududi, 1986: 129). Dengan hanya menyembah kepada Allah, manusia dapat menyempurnakan nilai kemanusiaannya. Tidak perlu mengikuti jalan lain yang hanya dapat menjerumuskan ke jurang kehinaan.

Perlu diingat bahwa ibadah apa saja yang akan dilaksanakan, sepatutnya dikerjakan dengan penuh ikhlas, yakni hanya ingin mendapat restu dari Allah, bukan untuk mencari muka, popularitas, kedudukan atau motivasi duniawi lainnya. Ibadah yang tidak didasari dengan keikhlasan, dengan sendirinya tidak bernilai apa-apa di sisi Allah (hanya sia-sia belaka).

Pentingnya keikhlasan sebagai syarat utama diterimanya suatu ibadah di sisi Allah, tergambar dalam kisah pengorbanan yang dilakukan oleh Qabil dan Habil. Qabil ditolak pengorbanannya karena dilakukan tanpa keikhlasan, sedangkan Habil diterima kurbannya karena dilakukannya dengan penuh keikhlasan.

Dikisahkan bahwa keikhlasan pengorbanan yang dilakukan oleh Habil karena ia memilih hartanya yang terbaik dan penuh rasa takwa untuk dipersembahkan kepada Allah. Sebaliknya, ketidakikhlasan dan ketidaktakwaan Qabil dalam melaksanakan pengorbanan itu, ia memilih hartanya yang rusak dan tidak layak untuk dipersembahkan sebagai kurban. 
Dengan demikian, kisah ini menunjukkan bahwa antara keikhlasan dan ketakwaan, tidak dapat dipisahkan antara satu dengan lainnya. Sementara itu iman merupakan pondasi atau dasar dari keikhlasan dan ketakwaan tersebut.

Dalam kaitan ini, al-Khalidiy (2000: 93) berkata bahwa dasar diterimanya amal ibadah di sisi Allah, sebab iman tidak dapat dilihat hanya dari zatnya saja. Amal ibadah itu tidak bermanfaat, bila tidak mengandung makna dan lepas dari kehidupannya. Seperti halnya buah, tidak akan tumbuh kecuali pada pohon. Begitu pula amal ibadah, tidak sahih dan tidak diterima di sisi Allah, kecuali jika bersumber dari iman dan dihasilkan dari ketakwaan.

Kaum muslimin yang memahami makna dari firman Allah yang berbunyi: (sesungguhnya Allah hanya menerima kurban dari orang-orang yang bertakwa), ia akan mengerjakan ibadah dengan penuh ketaatan. Mereka merasa takut tidak diterima ibadahnya, sehingga mereka tidak termasuk orangorang yang bertakwa.

\section{Jiwa yang Suci Mampu Mengendalikan Manusia dari Prilaku Kejahatan}

Kejahatan adalah tingkah laku manusia yang digolongkan sebagai perbuatan yang tidak disenangi, atau dalam istilah lain disebut dengan perbuatan jahat. Kadar kejahatan merupakan suatu hal yang abstrak, tidak dapat diraba, tetapi dapat dirasakan atau diduga, dan karenanya sangat rumit dan ruwet dalam menafsirkan suatu perbuatan jahat.

Dalam ilmu hukum, kejahatan dipandang sebagai suatu perbuatan yang melawan hukum. Ukuran melawan hukumnya suatu perbuatan, bukan saja harus ditinjau dari segi undang-undang atau hukum tertulis, melainkan juga harus ditinjau dari segi asas-asas umum dari hukum tidak tertulis (Leden Marpaung, 1991: 51).

Dari segi hukum pidana, suatu kejahatan dapat terjadi jika terdapat dua unsur pada pelakunya, yaitu: (1) adanya niat, dan (2) adanya kesempatan. Kedua unsur ini harus saling menunjang dalam pelaksanaan sebuah kejahatan, sebab meski seseorang itu berniat melakukan pembunuhan, tetapi jika kesempatan untuk melakukannya tidak ada, maka pembunuhan itu tidak terlaksana (Adami Chazawi, 2002: 14). 
Kalau peristiwa pembunuhan yang dilakukan oleh Qabil terhadap Habil dikaji dari segi hukum pidana, maka dapat dipahami bahwa peristiwa tersebut telah memenuhi unsur kejahatan pembunuhan. Dengan dilatarbelakangi rasa kejengkelan dalam hati sebagai akibat ditolaknya pengorbanannya, Qabil telah berniat membunuh Habil. Dengan perkataan yang meluncur dari mulutnya لأقتلنك (akan kubunuh kau), menunjukkan bahwa dalam hati Qabil sudah terbetik niat untuk membunuh. Karenanya, ketika kesempatan melakukan pembunuhan itu tiba, maka Qabil pun membunuh Habil dalam keadaan tanpa perlawanan.

Dalam melakukan pembunuhan tersebut, hati Qabil telah dikuasai oleh kejahatan dan dengki terhadap saudaranya. Setan mengalahkannya dan menutup hatinya dari kebenaran. Sesungguhnya ia mengetahui dirinya tidak berada pada pihak yang benar. Seharusnya ia mengoreksi sikap dan tingkah lakunya yang menyebabkan kurbannya ditolak oleh Allah. Setan telah menggiring Qabil kepada tingkatan yang paling berbahaya, yaitu berpikir dan merencanakan untuk membunuh saudaranya.

Berbeda dengan sikap Qabil, meski Habil menerima ancaman pembunuhan dari saudaranya, tetapi ia sama sekali tidak memiliki niat yang sama, apalagi merencanakan untuk membunuh saudaranya. Bahkan, Habil menasehati saudaranya agar kembali ke jalan yang benar, sekaligus mengingatkan bahwa perbuatan membunuh itu merupakan dosa besar dan balasannya adalah neraka.

Menurut Sayyid Quthub (1991: 140), sikap Habil tersebut telah melukiskan kasih sayangnya kepada saudaranya. Tujuan utamanya adalah agar Qabil surut dari mengikuti dorongan hawa nafsunya, juga agar Qabil merasa malu melakukan pembunuhan terhadap saudaranya yang memiliki cinta damai, patuh, dan takwa. Ditunjukkan kepadanya dosa melakukan kejahatan pembunuhan, supaya ia menjauhinya. Ditunjukkan pula kebaikan orang yang terlepas dari dosa yang berlipat ganda. Dalam kaitan ini, al-Khalidiy (2000: 95) mengatakan bahwa jawaban perdamaian yang diajukan oleh Habil mengandung beberapa makna: (1) jawaban yang tenang dan lembut atas ancaman saudaranya; (2) menenangkan hati saudaranya bahwa ia tidak bermaksud melakukan pembunuhan; (3) menunjukkan tabiat yang tenang, jiwa yang beriman dan penuh kerelaan. 
Membalas suatu kejahatan dengan kejahatan serupa merupakan hal yang mudah, dan setiap orang pasti dapat melakukannya. Namun, mengatasi kejahatan dengan kebaikan merupakan suatu hal yang sangat sulit. Seseorang tidak akan mampu melakukan hal itu, kecuali ia memiliki jiwa besar, jiwa yang mulia, hati yang lembut dan penyayang, serta keimanan dan akhlak yang tinggi.

Perasaan takut kepada Allah pada diri seseorang, menimbulkan keimanan, ketakwaan, dan kedekatan kepada Allah. Keimanan itulah yang menghalanginya untuk melakukan hal-hal yang diharamkan dan berbuat kemaksiatan dan kemungkaran. Takut kepada Allah adalah katup pengaman bagi setiap individu maupun kelompok, sekaligus merupakan penjaga terkuat bagi mereka dari permusuhan, kelaliman, dan penghinaan (al-Khalidiy, 2000: 96).

Dengan demikian, Habil menghindarkan diri dari perbuatan membunuh, karena dalam dirinya tertanam hati yang bersih, jiwa yang suci, perasaan kasih sayang, dan prikemanusiaan yang tinggi. Kesemuanya itu berpangkal tolak dari rasa keimanan dan ketakwaan kepada Allah swt.

Oleh karena Habil tidak berpikir untuk membunuh Qabil, maka ia telah keluar dari kemungkinan untuk menjadi pembunuh. Dengan demikian, terbunuhnya Habil tidak mengantarkan dirinya untuk masuk neraka, sebab sejak semula ia sudah menghindarkan diri dari keinginan untuk membunuh Qabil.

Memiliki sikap dan watak seperti sikap dan watak yang dimiliki oleh Habil, dapat menjauhkan seseorang untuk melakukan hal-hal yang haram dan mencegah mereka dari cara-cara yang mungkar dalam kehidupannya. Sikap dan watak seperti itulah yang seharusnya dimiliki oleh seseorang yang mengakui dirinya sebagai seorang mukmin. Jika tidak demikian, maka keimanan orang tersebut belum mencapai titik yang maksimal.

\section{Memetik Pelajaran dari Prilaku Burung}

Dari keseluruhan ciptaan Allah, meski manusia merupakan makhluk yang paling sempurna penciptaannya (QS al-Thin: 4), namun tidak berarti bahwa makhluk lainnya harus dikesampingkan. Terbukti dari banyaknya ayat Alquran yang menyuruh manusia untuk mengambil 'ibrah (perumpamaan) dari prilaku hewan dan burung. 
Burung gagak adalah seekor burung yang terkadang dinilai oleh manusia sebagai burung yang tidak berguna. Selain warna bulunya kurang menarik perhatian (hitam pekat), juga sering menjengkelkan petani karena suka memakan pisang yang terlambat ditebang (masak di pohon).

Namun demikian, bukan berarti bahwa burung gagak tidak memiliki manfaat sama sekali, sehingga harus dikesampingkan dalam berbagai aspek kehidupan manusia. Terbukti dalam QS al-Maidah (5): 31, disebutkan bahwa ternyata burung gagak memiliki jasa yang besar dalam sejarah kehidupan manusia, yakni memberi contoh kepada Qabil tentang cara menguburkan jenazah.

\section{Simpulan}

Kisah dua putera Adam, sebagaimana terdapat dalam QS al-Maidah (5): 27-31, yang pada umumnya ulama tafsir menyebutnya sebagai Qabil dan Habil, menceritakan bahwa awal mula ketidakcocokan antara keduanya disebabkan karena proses persembahan kurban yang dilakukannya. Dalam peristiwa itu, kurban dari salah satunya (Qabil) tidak diterima oleh Allah, sedangkan yang satunya lagi (Habil) diterima. Karena kurbannya ditolak, timbullah kejengkelan dan niat jahat dari Qabil untuk membunuh Habil, dan niat itu pun berhasil dilaksanakannya dengan baik. Setelah saudaranya terbunuh, barulah Qabil menyesali perbuatannya. Di tengah kondisi kebingungan mengenai mayat saudaranya, tiba-tiba datang burung gagak menggali lobang sebagai petunjuk baginya untuk menguburkan mayat saudaranya. Dari contoh yang diberikan burung gagak itulah, Qabil dapat mengetahui cara menguburkan mayat.

Pesan dakwah universal yang terkandung dalam kisah dua putera Adam, sebagaimana terdapat dalam QS al-Maidah (5): 27-31, antara lain dapat dikelompokkan sebagai berikut: (1) ketulusan niat dan ketakwaan bagi pelakunya merupakan salah satu syarat diterimanya ibadah di sisi Allah. Hal ini tergambar dalam sikap yang dimiliki Habil ketika akan mempersembahkan kurbannya. Itulah sebabnya sehingga pengorbanannya diterima di sisi Allah. Berbeda dengan Qabil, karena ia tidak ikhlas dalam melaksanakan pengorbanan, menyebabkan 
pengorbanannya tersebut ditolak oleh Allah swt, (2) jiwa suci yang dimiliki oleh seseorang akan mampu mengendalikan dirinya dari prilaku kejahatan. Hal ini tergambar dalam jiwa Habil yang mampu mengendalikan diri, sehingga ia tidak memberikan perlawanan ketika Qabil melakukan kejahatan pembunuhan terhadap dirinya, (3) memetik pelajaran dari keadaan dan prilaku makhluk ciptaan Tuhan lainnya. Hal ini diperoleh dari contoh yang diberikan oleh burung gagak kepada Qabil mengenai cara menguburkan mayat.

\section{DAFTAR PUSTAKA}

Arifin, Bey. Rangkaian Cerita dalam Al-Qur'an. Cet.XVII; Bandung: PT. Alma'arif, t.th.

Azra, Azyumardi (ed.). Sejarah dan 'Ulum al-Qur'an. Cet.I; Jakarta: Pustaka Firdaus, 1999.

Bisri, A. Mustofa. "Taat, Ibadah, dan Taqarrub (Bebas Menyendiri dengan Diri Sendiri)", dalam Nurcholish Madjid, et al., Puasa: Titian Menuju Rayyan. Cet. I; Yogyakarta: Pustaka Pelajar, 2000.

Chazawi, Adami. Pelajaran Hukum Pidana Bagian Ketiga. Cet. I; Jakarta: PT Raja Grafindo Persada, 2002.

Departemen Agama RI. Al-Qur'an dan Terjemahnya. Jakarta: Proyek Pengadaan Kitab Suci Al-Qur'an, 1985/1986.

Departemen Pendidikan dan Kebudayaan. Kamus Besar Bahasa Indonesia. Jakarta: Balai Pustaka, 1986.

Dewan Redaksi Ensiklopedi Islam. Ensiklopedi Islam. Cet. III; Jakarta: PT Ichtiar Baru van Hoeve, 1994.

Hafid, M. Radhi. Gaya Bahasa Kisah Al-Quran: Kajian Semiotika. Orasi Pengukuhan Jabatan Guru Besar yang disampaikan dalam sidang Senat Terbuka Luar Biasa IAIN Alauddin Ujungpandang pada tanggal 1 Juni 1998.

------. Nilai Edukatif Kisah Alquran. Disertasi yang diajukan pada Institut Agama Islam Negeri Sunan Kalijaga, Yogyakarta, 1994.

Hamka. Tafsir al-Azhar. Jakarta: PT Pustaka Panjimas, 1992.

Al-Khalidy, Shalah 'Abd al-Fattah. Ma'a Qishash al-Sabikin fiy al-Qur'an, ditrerjemahkan oleh Setiawan Budi Utomo dengan judul Kisah-kisah AlQur'an: Pelajaran dari Orang-orang Dahulu. Cet. I; Jakarta: Gema Insani Press, 2000.

Mahfud, Sahal. "Ibadah Sosial Tentukan Kualitas Iman", dalam Nurcholish Madjid, et al., Puasa: Titian Menuju Rayyan. Cet. I; Yogyakarta: Pustaka Pelajar, 2000.

Al-Maragiy, Ahmad Mushthafa. Tafsir al-Maragiy. Bairut: Dar al-Fikr, t.th. 
Marpaung, Leden. Unsur-unsur Perbuatan yang Dapat Dihukum (Delik). Cet. I; Jakarta: Sinar Grafika, 1991

Al-Maududi, Abul A'la Pengertian Agama, Ibadah dan Ketuhanan Yang Maha Esa dalam Al-Qur'an, diterjemahkan oleh Mahyuddin Syaf tanpa menyebut judul aslinya. Cet. I; Bandung: Sinar Baru, 1986.

Munawwir, Ahmad Warson. Al-Munawwir: Kamus Arab-Indonesia. Yogyakarta: Pondok Pesantren al-Munawwir, t.th.

Al-Qaththan, Manna'. Mabahi£ fiy 'Ulum al-Qur'an. Bairut : Muassasah alRisalah, t.th.

Quthub, Sayyid. Fiy ïlal al-Qur'an. Cet. VII; Bairut: Mazidah wa Manqahat, 1971.

Al-Qurthubiy, Abiy 'Abdillah Muhammad ibn Ahmad al-Anshariy. Al-Jami' li Ahkam al-Qur'an. Bairut: Dar al-Fikr li al-Thaba'ah wa al-Nasyr wa alTauzi', t.th.

Rachman, Luthfi. "Nilai Ikhlas dalam Puasa Ramadhan", dalam Nurcholish Madjid, et al. Puasa: Titian Menuju Rayyan. Cet. I; Yogyakarta: Pustaka Pelajar, 2000.

Al-Shabuniy, Muhammad 'Aliy. Shafwah al-Tafasir. Kairo: Dar al-Fikr, t.th.

Shihab, M. Quraish. Membumikan Al-Qur'an: Fungsi dan Peran Wahyu dalam Kerhidupan Umat. Bandung: Mizan, 1992.

-------. Mukjizat Al-Quran Ditinjau dari Aspek Kebahasaan, Isyarat Ilmiah dan Pemberitaan Gaib. Cet.IV; Bandung: Mizan, 1998.

-------. Tafsir al-Qur'an al-Karim: Tafsir atas Surah-surah Pendek Berdasarkan Urutan Turunnya Wahyu. Bandung: Pustaka Hidayah, 1997.

Al-Syawkaniy, Muhammad ibn 'Aliy ibn Muhammad. Fath al-Qadir bayn Fann al-Riwayah wa al-Dirayah min 'Ilm al-Tafsir. Bairut: Dar al-Fikr li alThaba'ah wa al-Tauzi', 1973. 